Sains Malaysiana 50(1)(2021): 109-121

http://dx.doi.org/10.17576/jsm-2021-5001-12

\title{
Optimization of Effervescent Tablet-Assisted Dispersive Liquid-Liquid Microextraction with Central Composite Design for Preconcentration of Stimulant Drug \\ (Pengoptimuman Tablet Berbuak Berbantukan Sebaran Pengekstrakan Mikro Cecair-Cecair dengan Reka Bentuk Komposit Berpusat untuk Kepekatan Awalan Dadah Stimulan)
}

\author{
Nurliyana Tazulazhar, SaW Hong Loh, Marinah Mohd Ariffin \& Wan Mohd Afiq Wan Mohd \\ KHALIK*
}

\begin{abstract}
The extraction efficiency of stimulant drug, namely caffeine, was investigated using a $2^{3}$ central composite design. The values of optimum extraction condition were set at $468 \mu \mathrm{L}$ of 1-dodecanol, 1 piece of effervescent tablet, and $22{ }^{\circ} \mathrm{C}$ of extraction temperature. An enrichment factor was calculated as 72 for $80 \mathrm{~mL}$ water sample. The run time was conducted in less than 6 min using a non-polar $C_{18}$ column and an isocratic mobile phase (methanol: water of 40:60

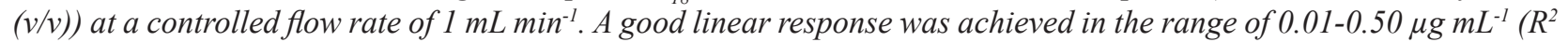

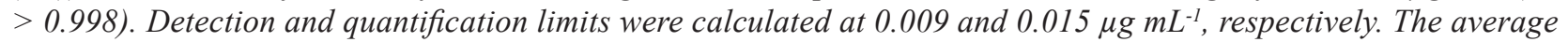
recoveries at two spiking concentration levels were within the range of $75-105 \%$ with $R S D<2 \%(n=3)$. Real samples namely beverages which contained caffeine and river water were tested using the proposed method, and the results

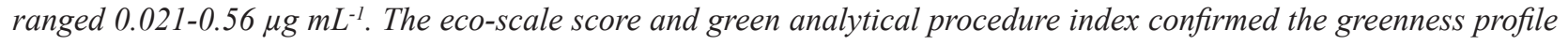
of the proposed method through a calculated score of 88 and has 6 green criteria, respectively.
\end{abstract}

Keywords: Pharmaceutically active compound; response surface methodology; stimulant drug

ABSTRAK

Keberkesanan pengekstrakan bagi jenis dadah perangsang, iaitu kafein telah dikaji menggunakan $2^{3}$ reka bentuk komposit berpusat. Pada keadaan optimum, nilai parameter ditetapkan pada $468 \mu \mathrm{L}$ 1-dodecanol, 1 tablet berbuak dan $22{ }^{\circ} \mathrm{C}$ suhu pengekstrakan. Faktor pengayaan dihitung pada nilai 72 bagi $80 \mathrm{~mL}$ sampel air. Waktu eksekusi dijalankan kurang dari 6 minit menggunakan turus tak berkutub $C_{18}$ dan fasa bergerak isokratik (metanol: air pada 40:60 (v/v)) pada kadar aliran terkawal $1 \mathrm{~mL} \mathrm{~min}^{-1}$. Respons kelinearan yang baik telah dicapai dalam julat 0.01-0.50 $\mu \mathrm{g} m L^{-1}$ ( $R^{2}>$ 0.998). Had pengesanan dan pengkuantitian telah dihitung masing-masing pada 0.009 dan $0.015 \mu \mathrm{g}$ $m L^{-1}$. Purata perolehan semula pada dua aras kepekatan sampel dipaku berada dalam julat 75-105\% dengan nilai $R S D<2 \%(n=3)$. Analisis sampel sebenar iaitu minuman yang mengandungi kafein dan air sungai telah diuji dengan

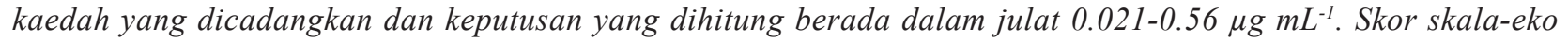
dan indeks prosedur analitis hijau telah mengesahkan profil hijau bagi kaedah yang dicadangkan masing-masing dengan nilai skor yang dihitung ialah 88 dan 6 kriteria hijau.

Kata kunci: Dadah perangsang; kaedah gerak balas permukaan; sebatian akif farmaseutis

\section{INTRODUCTION}

Dispersive liquid-liquid microextraction (DLLME) was first introduced by Rezaee et al. (2006) for pre-concentration of polyaromatic hydrocarbons in water. DLLME is a separation technique which offers numerous advantages, including simple operation, fast analysis, minimum amount of extraction solvent, and high enrichment factor of extracted analytes (Jing et al. 2018; Zgola-Grześkowiak \& Grześkowiak 2011). This technique is widely used for the determination of metals (Assadollahzadeh et al. 2014; Farajzadeh et al. 2010), pesticides (Cheng et al. 2011; Xia et al. 2008), and pharmaceutically active compounds (Khodadoust \& Ghaedi 2013; Shishov et al. 2019). The working principle is based on a ternary solvent system which consists of extraction solvent, disperser solvent and aqueous solution. 
Dispersive solvent should be miscible in aqueous and extraction solvent, while formation of a cloudy solution is due to the cosolvency (Yang et al. 2016). Dispersion of the extraction solvent into aqueous samples were subjected to centrifugation (Xu et al. 2011), direct injection (Yazdi et al. 2008), effervescent tablet (Liu et al. 2014), ultrasound (Yan et al. 2010), and vortexing (Hrouzková et al. 2017).

Effervescent tablet is one of the disperser-solventfree techniques in DLLME. This novel work was first introduced by Lasarte-Aragones et al. (2014) for the extraction of herbicides in water. Once the tablet has contacted with an aqueous solution, a simple reaction between the proton donor and carbon source (i.e. sodium carbonate) causes the production of gas microbubbles $\left(\mathrm{CO}_{2}\right)$. In the tablet form, the effervescence occurs from the bottom container to top position and the extractant solvent is uniformly distributed (Jiang et al. 2014). This approach accelerates the disperser solvent without additional energy. Other advantages include rapid, effective, reproducible, eliminating multi-stage operation, and low cost (Jiang et al. 2014; Wang et al. 2016; Zhou et al. 2019).

Caffeine (1,3,7-trimethylpurine-2,6-dione) that belongs to the methylxanthine class has medical properties such as a central nervous system stimulant. Caffeine has high solubility in water, can create hydrogen bonds at six positions, especially in the presence of amide group (Mahetaji et al. 2016). This micropollutant has gained attention due to high frequency of detection in environmental waters. Literature studies showed the potential of caffeine as a good chemical marker for water pollution (Buerge et al. 2003; Goncalves et al. 2017; Khalik et al. 2020). Different analytical methods, including solid phase extraction (Al-Qaim et al. 2017; Khalik \& Abdullah 2017; Khalik et al. 2016), solid phase microextraction (Gomes et al. 2013; Kotowska \& Bieńczyk 2013), and thin film microextraction (Mazlan et al. 2019; Zulkipli et al. 2019), were applied for preconcentration of caffeine in environmental waters. However, major drawbacks include single-use sorbent, high consumption organic solvents, tedious, and producing wastes after analysis.

To the best of our knowledge, the development of DLLME using effervescent tablet as a disperser agent for the preconcentration of caffeine in water has not been reported in literature. To construct the experimental work, a central composite design was applied and subjected to three variables, namely volume of extraction solvent, number of effervescent tablets, and extraction temperature. The experimental design was used to understand the interaction between variables. Method performance and the greenness profile of the proposed method were also tested.

\section{MATERIALS AND METHODS}

\section{CHEMICAL AND REAGENTS}

Caffeine standards ( $>98 \%$ ) were purchased from SigmaAldrich (Steinheim, Germany). Methanol (HPLC-grade), glycerine (ACS reagent $\geq 99.5 \%$ ), sodium bicarbonate (ACS reagent $\geq 99.7 \%$ ), and sodium hydrogen phosphate (Reagent Ph Eur 98\%) were purchased from Merck (Darmstadt, Germany). The stock solution of caffeine (5 $\left.\mu \mathrm{g} \mathrm{mL}^{-1}\right)$ was dissolved in methanol. The working solutions were prepared by appropriate dilution of the stock solution by deionized water produced by a Milli-Q system (Millipore, Bedford, MA, USA). All standard solutions were stored at $4{ }^{\circ} \mathrm{C}$ and brought to ambient temperature prior to use.

\section{INSTRUMENTATION}

The chromatographic separation was carried out with a HPLC Shimadzu system which was equipped with an autosampler (SIL-20A HT), vacuum degasser (DGU-20A 5R), system controller (LC-20AT), quaternary pump (LC-10ATVP), oven (CTO-10AS VP), series multiple wavelength detector (SPD-20A), and Apollo $\mathrm{C}_{18}$ column $(250 \mathrm{~mm} \times 4.6 \mathrm{~mm}, 5 \mu \mathrm{m})$. The final determination of caffeine was carried out at optimum separation condition by HPLC with the isocratic binary mobile phase which comprised 40:60 (v/v) of methanol: water. The flow rate was set at $1 \mathrm{~mL} \mathrm{~min}{ }^{-1}$. Meanwhile, the run time was 6 min and the retention time of caffeine was integrated at $3.70 \mathrm{~min}$. The optimum wavelength was set up at $275 \mathrm{~nm}$. Injection volume per analysis was $20 \mu \mathrm{L}$. Chromatographic data integration were performed using LabSolutions software.

\section{PREPARATION OF EFFERVESCENT TABLET}

In this study, the effervescent tablets were produced by using wet granulation method. Sodium bicarbonate (1 $\mathrm{g})$ and sodium hydrogen phosphate $(1 \mathrm{~g})$ were weighed into a glass mortar, and sufficiently ground to achieve a homogenous mixture, and adopted as the effervescent precursors. The mixture was then transferred into a weighing boat with dimension of $44 \mathrm{~mm} \times 44 \mathrm{~mm}$, and subsequently added with $1 \mathrm{~mL}$ glycerin (binder), and 1-dodecanol, $\mathrm{X}_{1}$ (as the extraction solvent). The binder was used to enhance the tablet hardness to a level whereby handling was possible. Finally, the homogenous mixture was transferred into a tablet mold with dimension of $2.5 \times 3.7 \mathrm{~cm}$, and subsequently compressed for 60 $\mathrm{s}$ to produce an effervescent tablet by a stainless-steel tablet press hammer. To maintain the tablet shape, the effervescent tablets (internal diameter of $15 \mathrm{~mm}$ ) were stored in an ice tray inside a chiller at $4{ }^{\circ} \mathrm{C}$. Tablet was brought to ambient temperature prior to extraction. 


\section{EXTRACTION PROCEDURE}

Deionized water $(80 \mathrm{~mL})$ was placed in a $100 \mathrm{~mL}$ beaker. Next, the beaker was placed on a hot plate to control water temperature and investigate the effect of temperature change $\left(\mathrm{X}_{3}\right)$. Subsequently, the desired number of effervescent tablets $\left(\mathrm{X}_{2}\right)$ was introduced into the solution for extraction process. The generation of effervescent occurred from bottom to the top of beaker. Therefore, it facilitated the caffeine molecule toward the extractant solvent, which was positioned at the top of solution. Once the effervescent reaction was completed, the top portion of solution (approximately $1 \mathrm{~mL}$ ) was withdrawn and transferred into a $1.5 \mathrm{~mL}$ Eppendorf tube (Figure 1).

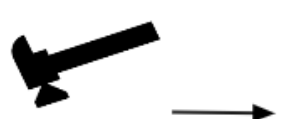

$\square$

Stage 1

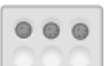

Stage 2

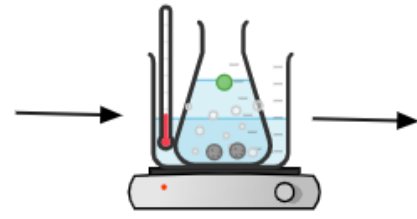

Stage 3

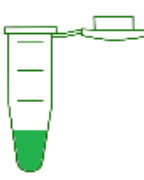

Stage 4

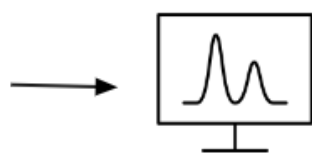

Stage 5

FIGURE 1. Experimental work involves five stages namely 1) preparation of effervescent tablet, 2) solidifying effervescent tablet, 3) extraction procedure, 4) pre-concentration and 5) chromatographic analysis

Then, the solution was vortexed for 2 min before the separated organic phase was collected by using a micropipette, filtered $(0.45 \mu \mathrm{m}$ cellulose membrane filter), and dissolved in $1 \mathrm{~mL}$ of methanol before injected into the LC system for final determination. No adjustment on solution $\mathrm{pH}$ and addition of salt were made since the reaction mechanism was based on acid-base reaction. Therefore, the acid neutralized the carbonate salt and the reaction was allowed to proceed in neutral condition. Under an optimum condition, the enrichment factor was calculated using (1):

$$
\mathrm{EF}=\frac{\mathrm{C}_{\mathrm{Org}}}{\mathrm{C}_{\mathrm{aq}}}
$$

whereas $\mathrm{C}_{\mathrm{Org}}$ is concentration of target analyte in organic phase; and $\mathrm{C}_{\mathrm{aq}}$ is concentration of target analyte in aqueous phase.

\section{OPTIMIZATION STRATEGY}

In $\mathrm{CCD}, 16$ experiments were randomly conducted to minimize bias in uncontrolled variables and the respective design matrix is shown in Table 1. The study of three variables, namely volume of extraction solvent $\left(\mathrm{X}_{1}\right)$, number of effervescent tablets $\left(\mathrm{X}_{2}\right)$, and extraction temperature $\left(\mathrm{X}_{3}\right)$, were subjected to optimization. The peak height was selected as the response (i.e. dependent variable) of study.

TABLE 1. Experimental variable and their levels

\begin{tabular}{lccccc}
\hline \multicolumn{1}{c}{ Variables } & $-\alpha$ & -1 & 0 & +1 & $+\alpha$ \\
\hline Extraction solvent $\left(\mathrm{X}_{1}\right)$ & 132 & 200 & 300 & 400 & 468 \\
No. of effervescent tablet $\left(\mathrm{X}_{2}\right)$ & 1 & 2 & 3 & 4 & 5 \\
Temperature $\left(\mathrm{X}_{3}\right)$ & 13 & 20 & 30 & 40 & 47 \\
\hline
\end{tabular}


The main effects, interaction effects, and quadratic effects were optimized and evaluated through this design. A $2^{3}$ full factorial design of CCD was generated with STATISTICA Version 10 (TIBCO software, Palo Alto, USA). A quadratic model was developed between the dependent and independent variables. The most important effects and variable interactions were assessed, followed by analysis of variance (ANOVA). A $p$-value $<0.05$ in the ANOVA table indicated a statistical significance of an effect at $95 \%$ confidence level, including the decision of either the model was accepted or rejected. Three-dimensional (3D) graphs were used to evaluate the interactive effect of two variables on the response.

\section{METHOD VALIDATION}

An analytical figure of merit was evaluated based on linearity, precision, accuracy, limit of detection, and limit of quantification. A calibration curve was obtained by a series of six standard solutions, ranging from 0.01 to $0.50 \mu \mathrm{g} \mathrm{mL}^{-1}$. Detection and quantification limits were calculated by linear regression method based on standard deviation of the lowest concentration and slope. The lowest concentration spiked was $0.01 \mu \mathrm{g} \mathrm{mL}^{-1}$ and triplicate analysis was performed. Extraction recovery was calculated by the following mathematical expression (2):

$$
\% \mathrm{ER}=\mathrm{EF} \times \frac{\mathrm{V}_{\text {Org }}}{\mathrm{V}_{\mathrm{aq}}} \times 100 \%
$$

where $\mathrm{V}_{\mathrm{Org}}$, and $\mathrm{V}_{\mathrm{aq}}$ are the concentrations of caffeine in organic and aqueous phases, respectively. The precision was evaluated through the repeatability (intra-day) and reproducibility (inter-day) assay of the method with water samples spiked with caffeine standard solution. Both assays were calculated as \% RSD with respect to the measurements made in triplicate $(n=3)$. Expanded uncertainty was calculated by using (3):

$$
U=k \sqrt{u_{c a l}^{2}+u_{\text {true }}^{2}+u_{\text {prec }}^{2}+u_{\text {LOD }}^{2}}
$$

where $u_{c a l}$ is defined as uncertainty from calibration curve; $u_{\text {true }}$ is uncertainty calculated from recovery (trueness); $u_{\text {prec }}$ is uncertainty produced from precision; $u_{L O D}$ is uncertainty derived from detection limit and $\mathrm{k}$ is coverage factor, 2 (El-Deen \& Shimizu 2019). For real sample analysis, water samples were extracted in the same manner and collected from Sungai Dungun, Malaysia. Two spiked beverage samples were also applied during this work.

\section{GREEN EVALUATION ASSESSMENT}

The green profile of the proposed method was tested subject to analytical eco-scale and green analytical practice index (GAPI). Analytical eco-scale is a semi quantitative tool, in which the calculation is based on maximum score of 100. Penalty points was subtracted from a base 100 for non-green aspects, which were linked to four parameters, namely amount of reagent used, hazardousness, energy consumption, and waste production. Eco-scale score was classified as ideal (100), excellent $(>75)$, acceptable $(50-75)$ and inadequate $(<50)$, respectively (Galuszka et al. 2012; Mohamed \& Lamie 2016; Tobiszewski et al. 2014). In this work, amount of reagent used (methanol, 1-dodecanol, sodium bicarbonate, sodium hydrogen phosphate) and their hazard levels, energy consumption (analysis using HPLC-UV) and waste production (residue of extraction solvent and HPLC mobile phase) were subjected to eco-scale analysis.

GAPI is a qualitative index used to evaluate the greenness method from sampling procedure to final analysis. Evaluation in GAPI involved 15 parameters, namely sample preparation (collection (labeled as 1), preservation (2), transportation (3), storage (4), pretreatment (5), scale of extraction (6), consumption of solvent or reagent (7), and additional treatment (8)) reagent and solvents (amount (9), health (10) and safety hazard (11)), instrumentation (energy (12), occupational hazard (13), waste (14), and waste treatment (15)). Classification of greenness for each category was expressed in pictogram represented by three colors, namely green (low), yellow (medium) and red (high) environmental impact, respectively. Detail evaluation of GAPI was adopted from Płotka-Wasylka (2018).

\section{RESULTS AND DISCUSSION}

\section{OPTIMIZATION OF CCD MODEL}

CCD strategy was subjected to: find highest response of peak height (chromatographic analysis) for caffeine, and identify the variable which has strongest influence on extraction efficiency in terms of linear or curvature effects. The optimization plot (Figure 2) showed the predicted conditions for the optimum point and desirability of prediction. The second-order polynomial equation obtained for the optimized variables is given by (4):

Peak Height $=5544+289 \mathrm{X}_{1}+2858 \mathrm{X}_{2}+1634 \mathrm{X}_{3}-0.2 \mathrm{X}_{1}^{2}$ $-1487 \mathrm{X}_{2}^{2}-40 \mathrm{X}_{3}^{2}-29.6 \mathrm{X}_{1} \mathrm{X}^{2}-2.2 \mathrm{X}_{1} \mathrm{X}_{3}+475 \mathrm{X}_{2} \mathrm{X}_{3}$

The ANOVA summary showed that the mathematical model was significant with $p$-value $<0.05$. $\mathrm{R}^{2}$ was loosely interpreted as the proportion of variability in data explained by ANOVA (Shiri et al. 2017). The $\mathrm{R}^{2}$ statistic indicated that the model explained $88 \%$ of the variability. The adjusted $\mathrm{R}^{2}$ was calculated at 
$84 \%$ of variability. A good fitted model should have a minimum $\mathrm{R}^{2}$ of $80 \%$. The positive sign showed in the equation showed the case when peak height response was enhanced, when passing from the lowest to highest coded level. In this model, a desirability function of 1.0 was recorded. The desirability of 1 was assigned for maximum response of peak height (19897), 0.5 for middle (657), and 0 for minimum (140). A lack-of-fit p-value of 0.78 implied that it was not significantly associated to pure error, and thus the acquired dataset was reliable.

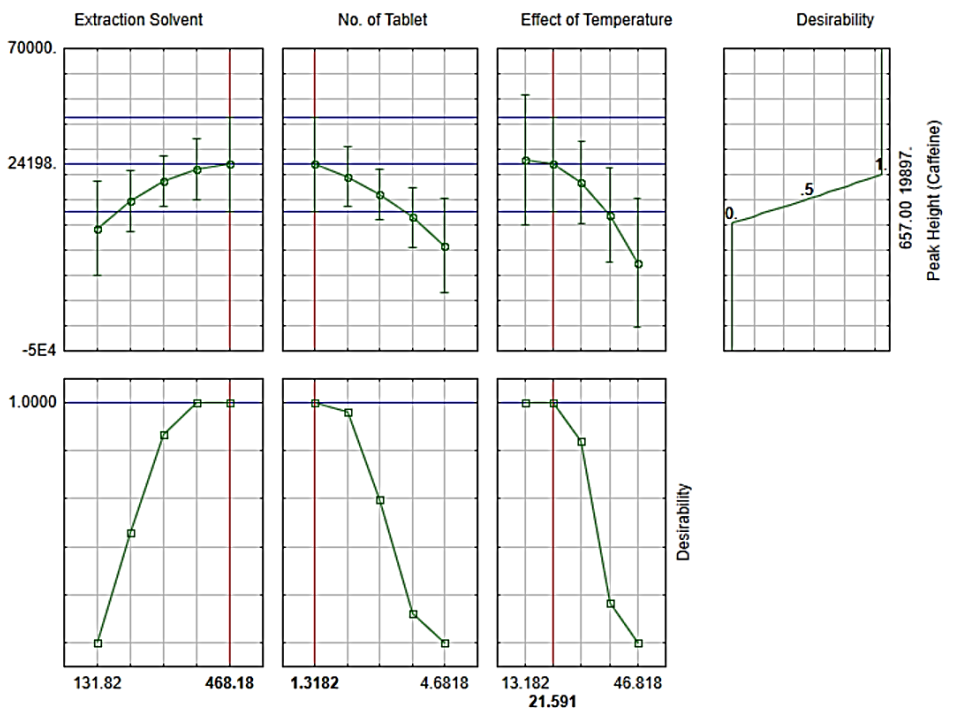

FIGURE 2. Optimizer plots for variables studied

The optimum working condition of extraction procedures as suggested by the model was $468 \mu \mathrm{L}$ of 1-dodecanol, 1 piece of effervescent tablet, with extraction temperature of $22{ }^{\circ} \mathrm{C}$. A $p$-value $<0.05$ signifies the statistical significance of an effect at $95 \%$ confidence level (Table 2). The enrichment factor at optimum condition was recorded at 72 for $80 \mathrm{~mL}$ of sample volume. The normality assumption was satisfied as the residuals in the plot distributed along a straight line (Figure 3). Positioning residuals close to straight lines explained that the error was normally distributed, and the mathematical model adequately fit the data (Sun et al. 2013). Therefore, utilization of the $3 \mathrm{D}$ response surface as predictive tools was valid for obtain responses over the whole variable uncertainty range (Farajzadeh et al. 2010).

TABLE 2. Analysis of variance (ANOVA) for the second-order regression model

\begin{tabular}{lccccc}
\hline \multicolumn{1}{c}{ Factor } & SS & Df & MS & F & P \\
\hline (1) Extraction solvent (L) & 8030364 & 1 & 803036 & 0.43 & 0.53 \\
Extraction solvent (Q) & 4104187 & 1 & 4104187 & 2.22 & 0.18 \\
(2) No. of effervescent tablet (L) & 648627 & 1 & 648627 & 0.35 & 0.57 \\
No. of effervescent tablet (Q) & 2050801 & 1 & 2050801 & 1.11 & 0.33 \\
(3) Effect of temperature (L) & 224494 & 1 & 224494 & 0.12 & 0.73 \\
Effect of temperature (Q) & 15280908 & 1 & 15280908 & 8.29 & 0.02 \\
1L by 2L & 7000402 & 1 & 7000402 & 3.80 & 0.09 \\
1L by 3L & 3913028 & 1 & 3913028 & 2.12 & 0.19 \\
2L by 3L & 18060451 & 1 & 18060451 & 9.80 & 0.02 \\
Error & 11048945 & 6 & 1841491 & & \\
Total SS & 57297403 & 15 & & & \\
\hline
\end{tabular}




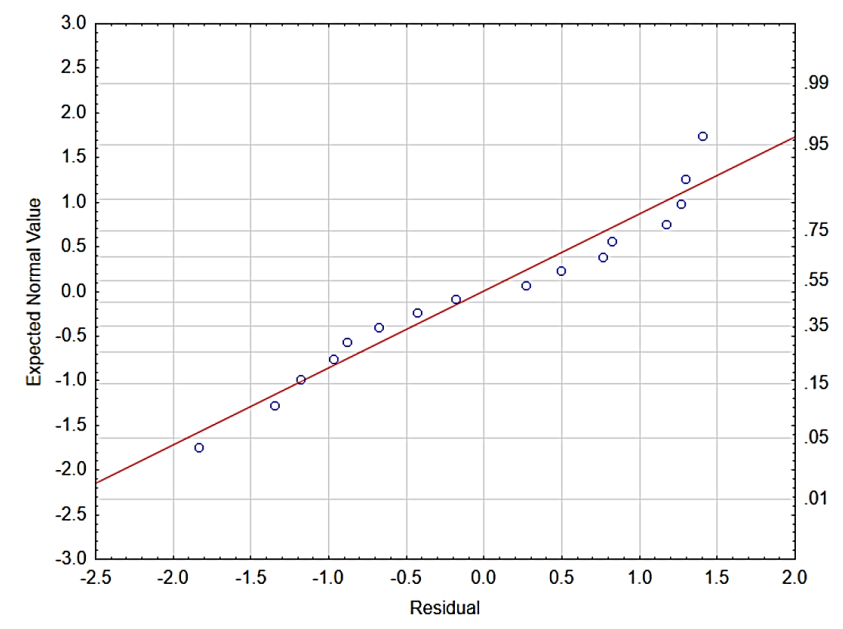

FIGURE 3. Normal probability plot

\section{EFFECT VOLUME OF SOLVENT EXTRACTION}

The effect of the volume of 1-dodecanol (extracting solvent) on the extraction efficiency was investigated. An ideal volume required was important to determine if caffeine was effectively extracted in the organic phase. The results illustrated in Figure 4 shows that by increasing the volume of 1-dodecanol, the peak height response increased, and optimized when it reached volume 468 $\mu \mathrm{L}$. The 1-dodecanol $\left(\log \mathrm{k}_{\mathrm{ow}} 5.13\right)$ will become a good extractant as the solvent fulfilled several requirements, such as hydrophobic solvent (solubility $0.004 \mathrm{~g} \mathrm{~L}^{-1}$ ), low volatility, low density $\left(0.830 \mathrm{mg} \mathrm{L}^{-1}\right)$, and low melting point of below room temperature $\left(22-24{ }^{\circ} \mathrm{C}\right)$ (Chaiyamate et al. 2018; Jing et al. 2018; Przyjazny 2019). Hydrophobic end and hydrogen bond donors played a significant role in extracting the targeted analyte $(\mathrm{Hu}$ et al. 2017; Zheng et al. 2017).
Caffeine has high $\mathrm{pKa}=10.4$, which implies that the compound has weak acid dissociation. Caffeine has low $\log \mathrm{K}_{\mathrm{ow}} 0.07$, a relative indicator of high solubility in water. The contribution of 1-docecanol to extract caffeine in the CCD model reached $47.78 \%$. Therefore, it required a high amount of extraction solvent to overcome the waterloving characteristic of caffeine. The chromatographic response reflected that low amount of extraction solvent has ideally given minimal impact on the analyte transferred. When the volume of 1-dodecanol was increased, the transition from yellow to dark red color was observed. Despite the quadratic effect for scale studied did not turn up into significant levels, the increment of peak height response showed a synergistic effect on extraction efficiency. Contour curve presented in Figure 4 shows an infinitive number the relations between two variables, while the extraction temperature was maintained at central point. Therefore, $468 \mu \mathrm{L}$ of 1-dodecanol was chosen as the optimal condition.
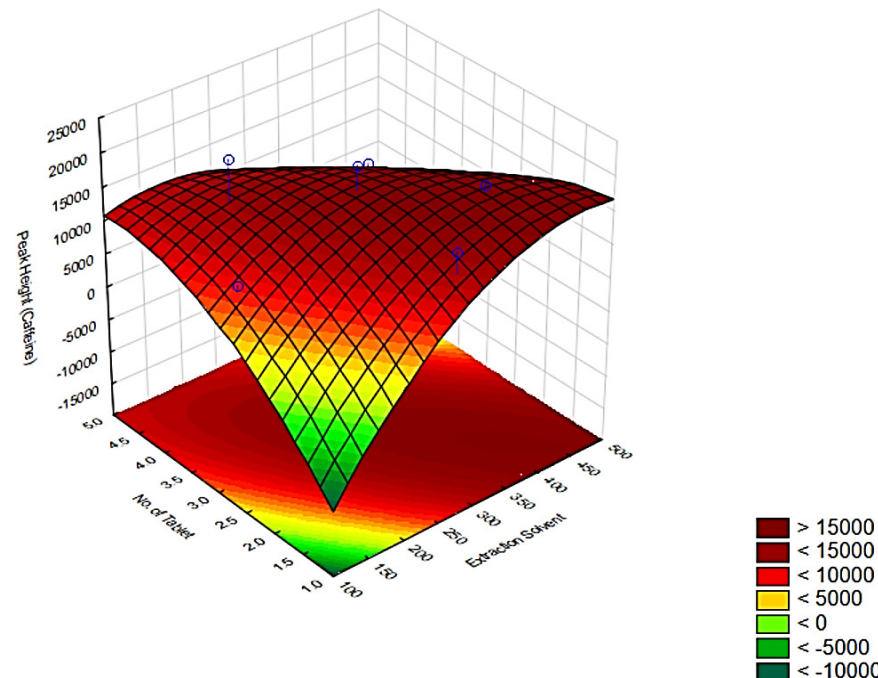

FIGURE 4. 3D response of interaction term between no. of effervescent tablet $v s$ volume of extraction solvent 
EFFECT AN AMOUNT OF EFFERVESCENT TABLET

The effect of amount of effervescent tablet (dispersion agent) on the extraction efficiency was investigated. Quick formation of fine bubble facilitated mass transfer of caffeine to 1-dodecanol. The role of the effervescent tablet in enhancing the peak height response contributed up to $38.89 \%$. In this work, 1 effervescent tablet was sufficient to disperse 1-dodecanol in extracting caffeine in aqueous phase. Therefore, under a suitable condition, the adjustment of temperature has a synergistic effect toward releasing the small bubble from effervescent tablet, by considering $62.38 \%$ contribution of the interaction of $\mathrm{X}_{2} \mathrm{X}_{3}$. An elliptical contour indicated a good interaction between number of effervescent tablet and an adjustment of water temperature. A small surface confined in contour diagram indicated the high response obtained during caffeine extraction.

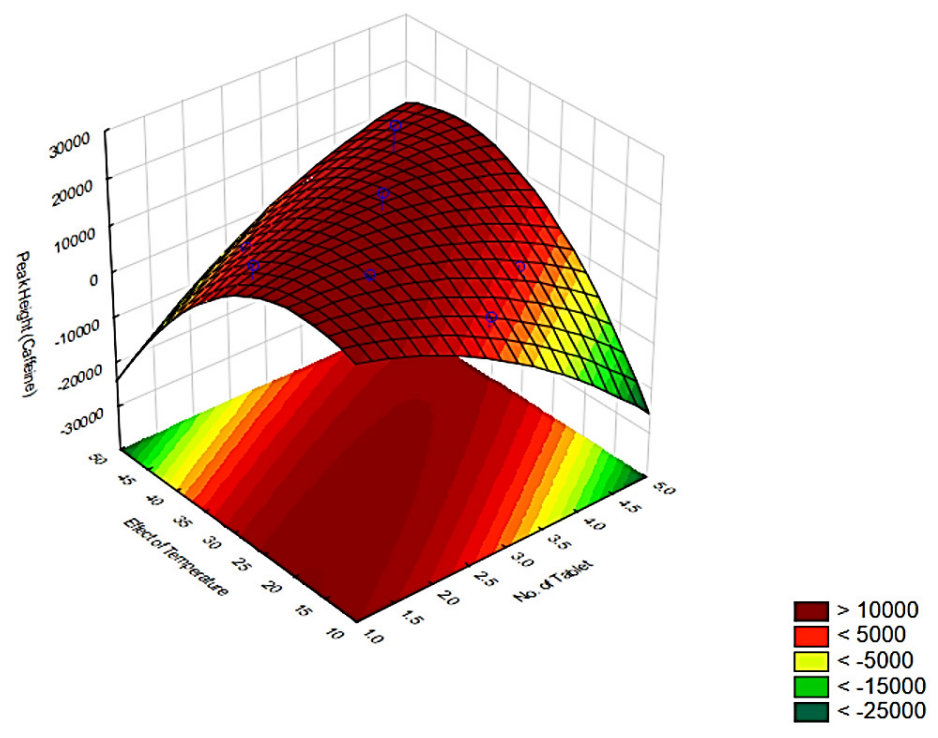

FIGURE 5. 3D response of interaction term between effect of temperature vs no. of effervescent tablet

Despite the optimum setting was recorded at 22 ${ }^{\circ} \mathrm{C}$, the contour diagram clearly showed a similar tone colour within the range of $10-25^{\circ} \mathrm{C}$ (Figure 5). Therefore, it gave an idea that the suitable temperature not only maintained the 1-dodecanol in liquid form, but also aided the dissolution process of effervescent tablet into aqueous phase. Also, temperature was considered a robust variable for the extraction process. Small changes of temperature did not disseminate the production of $\mathrm{CO}_{2}$.

\section{EFFECT OF TEMPERATURE CHANGES}

Temperature is known an important variable, which can affect mass transfer rate of analyte and increase contact area between extraction solvent and aqueous solution. The influence of water temperature was investigated in the range of $13-47^{\circ} \mathrm{C}$. This range included the melting point of 1-dodecanol at $22-24^{\circ} \mathrm{C}$. The response of peak height showed a decrement trend from $22^{\circ} \mathrm{C}$ to $47^{\circ} \mathrm{C}$ in Figure 6. Higher temperature resulted in a significant change with the size of 1-dodecanol micro drop, which negatively created inconsistency in extraction performance. Therefore, water temperature of $22{ }^{\circ} \mathrm{C}$ was chosen for the subsequent experiment in method validation works. Contour plot generated from this relation was centred to 0 point, and thus reflected that the scaled studies did not provide a significant difference at 95\% confident level.

\section{ANALYTICAL FIGURE OR MERITS}

A good linearity range was achieved at a satisfactory level of $R^{2}>0.998$ (range 0.01-0.50 $\mu \mathrm{g} \mathrm{mL}^{-1}$ ). The sensitivity of the developed method was shown by calculating the limit of detection and quantification (LOD 

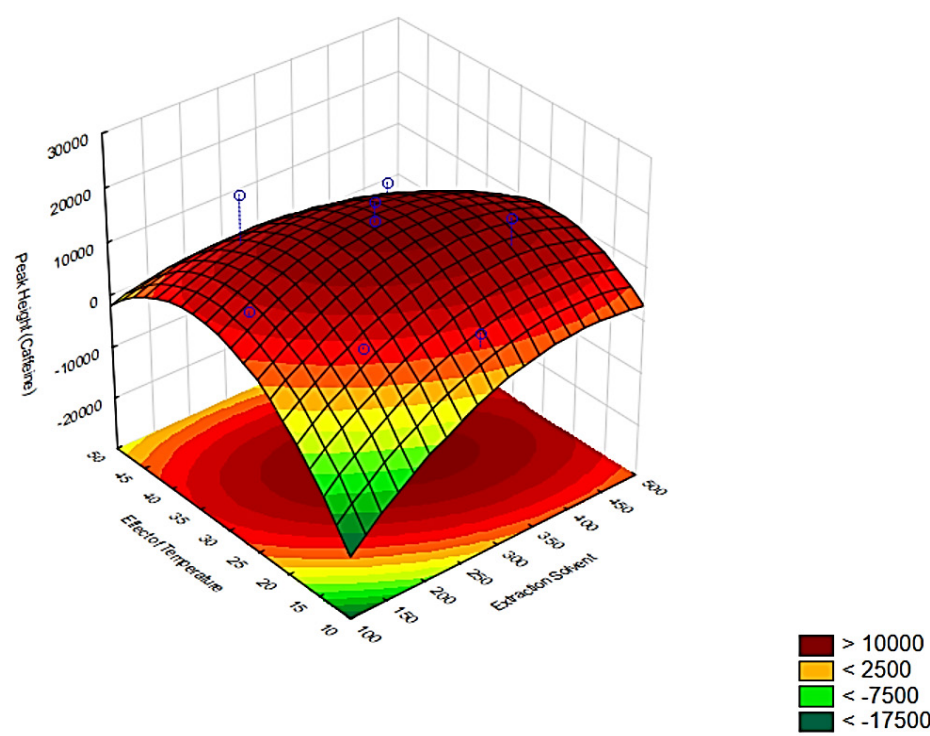

FIGURE 6. 3D response of interaction term between effect of temperature $v s$ volume of extraction solvent

and LOQ), which were recorded at 0.009 and $0.015 \mu \mathrm{g} \mathrm{mL}^{-1}$, respectively. The enrichment factor was calculated as 72 for $80 \mathrm{~mL}$ water sample. Good extraction recovery of 75 $105 \%$ was recorded when three concentrations of spiked caffeine $\left(0.5,0.1\right.$, and $\left.0.03 \mu \mathrm{g} \mathrm{mL}^{-1}\right)$ were introduced into the $80 \mathrm{~mL}$ water samples. The repeatability test indicated low bias measurement (i.e. $<2$ RSD), which was below the acceptable value proposed by AOAC guidelines. Expanded uncertainty was calculated at $7.04 \%$ in which uncertainty for LOD calculation was high $(0.9 \%)$. Real samples using Sungai Dungun water recorded caffeine residue at concentration level of $0.021 \mu \mathrm{g} \mathrm{mL}^{-1}$. In addition, extracted solvent contained 0.06 and $0.56 \mu \mathrm{g} \mathrm{mL}^{-1}$ of caffeine when water spiked with $100 \mu \mathrm{L}$ commercial beverages were brought from the local shop. Figures of merit for method performance are summarised in Table 3 . Chromatographic detection of spiked beverage solution in river water and beverages samples are as shown in Figure 7.

TABLE 3. Analytical performance of extraction method for determination caffeine in river water and beverages samples

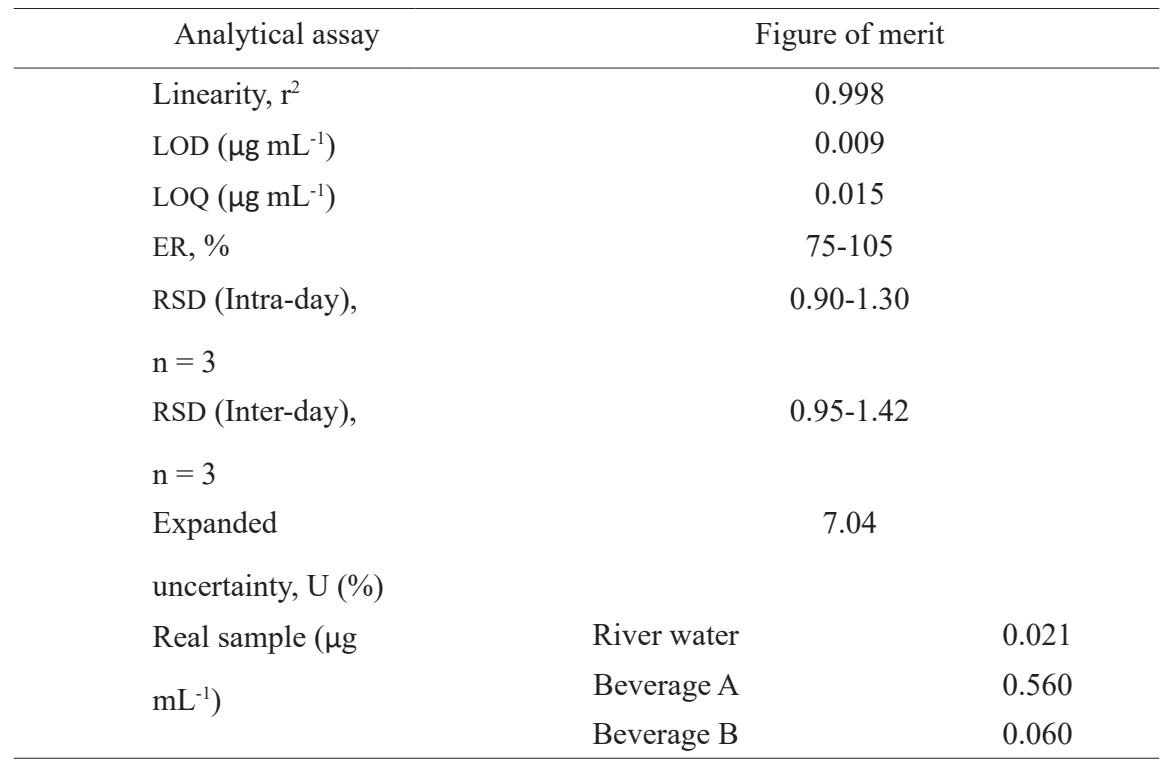




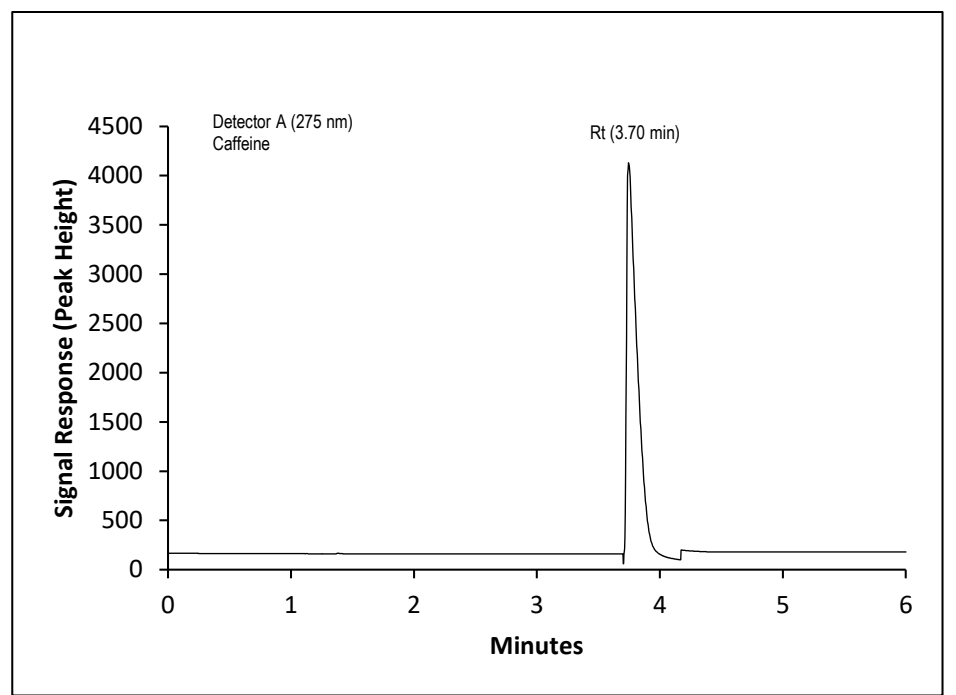

FIGURE 7. Caffeine chromatogram in fortified sample using beverage solution for HPLC analysis

\section{ANALYTICAL ECO-SCALE AND GAPI}

The detailed total penalty points for the proposed method are presented in Table 4 . The proposed method showed to be a green methodology, which fell under excellent score. On the eco-scale it recorded a high score of 88 and used low energy, either for extraction or chromatographic analysis. The green analytical procedure index showed that the proposed method was a green method based on criteria such as no preservation for targeted analyte (2), no additional treatment after extraction (8), usage of low amount extraction solvent, low safety and occupational hazard $(9,11,13)$, and produce minimal waste after analysis (14). Pictogram pattern for proposed method are illustrated in Figure 8.

TABLE 4 . The penalty points calculated for the extraction methods of caffeine in water samples

\begin{tabular}{llcc}
\hline \multicolumn{1}{c}{ Assessment criteria } & \multicolumn{1}{c}{ Sub-criteria } & Consumption & Penalty points \\
\hline Reagents & Type (Hazard) & $10-100 \mathrm{~mL}$ & 6 \\
& Methanol (3) & $<10 \mathrm{~mL}$ & 2 \\
& 1-dodecanol (2) & $<10 \mathrm{~mL}$ & 1 \\
& Glycerine (1) & $<10 \mathrm{~g}$ & 1 \\
& Sodium bicarbonate (1) & $<10 \mathrm{~g}$ & 0 \\
Instruments & Sodium hydrogen phosphate (0) & & 1 \\
& Energy & & 0 \\
& HPLC-UV & & 1 \\
Waste & Occupational hazard & & 11 \\
Total penalty point & & & 88 \\
Eco-scale score & & & \\
\hline
\end{tabular}




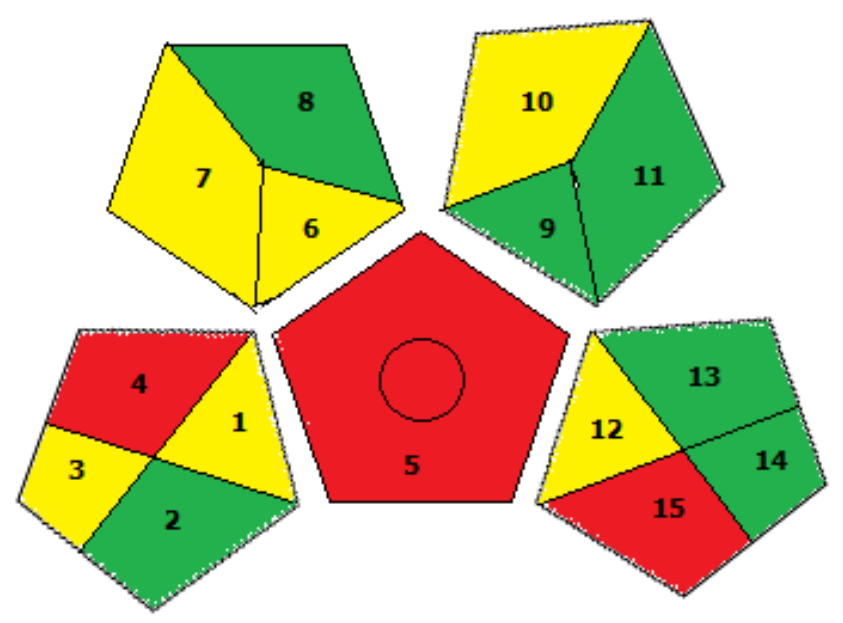

FIGURE 8. GAPI assessment for effervescent tablet-assisted dispersive liquidliquid microextraction method

\section{COMPARISON OF EA-DDLME WITH OTHER MICROEXTRACTION METHODS}

Extraction efficiency for preconcentration of caffeine in water samples was compared with other microextraction methods in Table 5. This work offered some advantages on method performances which included: short time required for sample preparation, extraction and instrumental analysis, highly sensitive to wide linear range at $\mu \mathrm{g} \mathrm{L}^{-1}$, and low detection. The proposed method used central composite design aid to investigate the effect and main interaction between variables. Precision of the proposed method was comparable with other reported microextraction methods, in-line for low level concentration (80-120\%). Indeed, bias was calculated lower than other microextraction methods. In fact, the dissolution of tablet gave an advantage on short extraction time. During experimental work, it required less than $3 \mathrm{~min}$ rather than $11 \mathrm{~min}$ (thin film), $5 \mathrm{~min}$ (dispersive by using centrifuge) and $60 \mathrm{~min}$ (solid phase by using PDMS/DVB), respectively (Gomes et al. 2013; Mazlan et al. 2019; Yao et al. 2011).

TABLE 5. Comparison of method performance with other microextraction techniques

\begin{tabular}{|c|c|c|c|c|c|c|}
\hline Method & Instrument & Linearity & $\begin{array}{c}\text { LOD } \\
\text { (ng mL-1 }\end{array}$ & $\%$ ER & $\%$ RSD & Reference \\
\hline LLME & HPLC-UV & 0.995 & 30 & 101 & $<6$ & Shishov et al. (2019) \\
\hline SPME & GCxGC-MS & 0.990 & 64.6 & - & $<14.4$ & Gomes et al. (2013) \\
\hline DLLME & HPLC-UV & 0.999 & 55.8 & $<107$ & - & Yao et al. (2011) \\
\hline TFME & HPLC-UV & 0.996 & 0.06 & 98.50 & 7.71 & Mazlan et al. (2019) \\
\hline TFME & HPLC-UV & 0.993 & 0.13 & 94.80 & 3 & Zulkipli et al. (2019) \\
\hline BAME & GC-MS & 0.992 & 0.005 & 85.2 & 4.5 & Neng and Nogueira (2012) \\
\hline EA-DLLME & HPLC-UV & 0.998 & 9 & $75-105$ & 2 & This study \\
\hline
\end{tabular}




\section{CONCLUSION}

This work proposed an effervescent tablet assisted dispersive liquid-liquid microextraction for the preconcentration of caffeine in environmental waters. The main benefits of the proposed method were rapidity, low cost, and eliminating toxic solvent usage in the extraction process. Analytical eco-scale and GAPI have given concrete evidence about the greenness profile of the proposed method. In future work, the study aims to replace the extraction solvent with ionic liquid to enhance the green analytical criteria. In addition, the proposed method may be utilized for determination of other stimulant drugs to strengthen the applicability aspect.

\section{ACKNOWLEDGEMENTS}

The authors acknowledge the Ministry of Higher Education, Malaysia and Universiti Malaysia Terengganu for providing financial support under the research grant FRGS/1/2019/STG01/ UMT/03/3 (Vot 59585).

\section{REFERENCES}

Al-Qaim, F.F., Jusof, S.H., Abdullah, M.P., Mussa, Z.H., Tahrim, N.A., Khalik, W.M.A.W.M. \& Othman, M.R. 2017. Determination of caffeine in surface water using solid phase extraction and high performance liquid chromatography. Malaysian Journal of Analytical Sciences 21(1): 95-104.

Asadollahzadeh, M., Tavakoli, H., Torab-Mostaedi, M., Hosseini, G. \& Hemmati, A. 2014. Response surface methodology based on central composite design as a chemometric tool for optimization of dispersive-solidification liquid-liquid microextraction for speciation of inorganic arsenic in environmental water samples. Talanta 123: 25-31.

Buerge, I.J., Poiger, T., Müller, M.D. \& Buser, H.R. 2003. Caffeine, an anthropogenic marker for wastewater contamination of surface waters. Environmental Science \& Technology 37(4): 691-700.

Chaiyamate, P., Seebunrueng, K. \& Srijaranai, S. 2018. Vortex-assisted low density solvent and surfactant based dispersive liquid-liquid microextraction for sensitive spectrophotometric determination of cobalt. RSC Advances 8(13): 7243-7251.

Cheng, J., Xiao, J., Zhou, Y., Xia, Y., Guo, F. \& Li, J. 2011. Dispersive liquid-liquid microextraction based on solidification of floating organic droplet method for the determination of diethofencarb and pyrimethanil in aqueous samples. Microchimica Acta 172(1-2): 51-55.

El-Deen, A.K. \& Shimizu, K. 2019. Deep eutectic solvent as a novel disperser in dispersive liquid-liquid microextraction based on solidification of floating organic droplet (DLLMESFOD) for preconcentration of steroids in water samples: Assessment of the method deleterious impact on the environment using analytical eco-scale and green analytical procedure index. Microchemical Journal 149: 103988.
Farajzadeh, M.A., Bahram, M. \& Vardast, M.R. 2010. Central composite design applied to optimization of dispersive liquid-liquid microextraction of $\mathrm{Cu}$ (II) and $\mathrm{Zn}$ (II) in water followed by high performance liquid chromatography determination. Clean-Soil, Air, Water 38(5-6): 466-477.

Gałuszka, A., Migaszewski, Z.M., Konieczka, P. \& Namieśnik, J. 2012. Analytical eco-scale for assessing the greenness of analytical procedures. TrAC Trends in Analytical Chemistry 37: 61-72.

Gomes, P.C.L., Barnes, B.B., Santos-Neto, Á.J., Lancas, F.M. \& Snow, N.H. 2013. Determination of steroids, caffeine and methylparaben in water using solid phase microextractioncomprehensive two dimensional gas chromatography-time of flight mass spectrometry. Journal of Chromatography A 1299: 126-130.

Gonçalves, E.S., Rodrigues, S.V. \& Silva-Filho, E.V.D. 2017. The use of caffeine as a chemical marker of domestic wastewater contamination in surface waters: seasonal and spatial variations in Teresópolis, Brazil. Revista Ambiente \& Água 12(2): 192-202.

Hrouzková, S., Brišová, M. \& Szarka, A. 2017. Development of fast, efficient and ecological method employing vortexassisted dispersive liquid-liquid microextraction combined with fast gas chromatography-mass spectrometry for pesticide residues analysis in alcohol-content samples. Journal of Chromatography A 1506: 18-26.

Hu, S., Yang, X., Xue, J., Chen, X., Bai, X.H. \& Yu, Z.H. 2017. Graphene/dodecanol floating solidification microextraction for the preconcentration of trace levels of cinnamic acid derivatives in traditional Chinese medicines. Journal of Separation Science 40(14): 2959-2966.

Jiang, W., Chen, X., Liu, F., You, X. \& Xue, J. 2014. Effervescenceassisted dispersive liquid-liquid microextraction using a solid effervescent agent as a novel dispersion technique for the analysis of fungicides in apple juice. Journal of Separation Science 37(21): 3157-3163.

Jing, X., Zhang, J., Zhu, J., Chen, Z., Yi, L. \& Wang, X. 2018. Effervescent-assisted dispersive liquid-liquid microextraction based on the solidification of floating organic droplets for the determination of fungicides in vinegar and juice. Food Additives \& Contaminants: Part A 35(11): 2128-2134.

Khalik, W.M.A.W.M. \& Abdullah, M.P. 2017. Solid phase extraction method for caffeine analysis in water: A mini review. Journal of Advanced Chemical Sciences 3(2): 485489.

Khalik, W.M.A.W.M., Loh, S.H., Albani, H., Alias, S.A.S. \& Rahman, K.U. 2020. Caffeine residue in Terengganu River basins in Malaysia: Distribution and risk assessment. Nature Environment and Pollution Technology 19(2): 711719.

Khalik, W.M.A.W.M., Abdullah, M.P., Baharudin, F.K. \& Zulkepli, S.A. 2016. Optimization of extraction procedure for determination of caffeine residue in water. Journal of Materials and Environmental Sciences 7(3): 720-728.

Khodadoust, S. \& Ghaedi, M. 2013. Optimization of dispersive liquid-liquid microextraction with central composite design 
for preconcentration of chlordiazepoxide drug and its determination by HPLC-UV. Journal of Separation Science 36(11): 1734-1742.

Kotowska, U. \& Bieńczyk, K. 2013. Use of direct immersion solid-phase microextraction on polyacrylate and polydimethylsiloxane stationary phases for simultaneous determination of the neutral and basic pharmaceuticals in wastewater. Open Chemistry 11(10): 1634-1643.

Lasarte-Aragonés, G., Lucena, R., Cárdenas, S. \& Valcárcel, M. 2014. Effervescence assisted dispersive liquid-liquid microextraction with extractant removal by magnetic nanoparticles. Analytica Chimica Acta 807: 61-66.

Liu, X., Zhigang, S., Peng, W., Chang, L., Zhiqiang, Z. \& Donghui, L. 2014. Effervescence assisted on-site liquid phase microextraction for the determination of five triazine herbicides in water. Journal of Chromatography A 1371: 58-64.

Mahetaji, K., Mann, G., Marchetti, S., Raufdeen, F. \& Singh, N. 2016. An interdisciplinary investigation into alcohol, caffeine, and prozac. Master Thesis, McMaster University. (Unpublised).

Mazlan, A.F., Loh, S.H. \& Khalik, W.M.A.W. M. 2019. Optimization of $\mathrm{C}_{18}$-cellulose triacetate thin film for analysis of caffeine residue in water. Asian Journal of Chemistry 31(9): 2101-2106.

Mohamed, H.M. \& Lamie, N.T. 2016. Analytical ecoscale for assessing the greenness of a developed RPHPLCmethod used for simultaneous analysis of combined antihypertensive medications. Journal of AOAC International 99(5): 1260-1265.

Neng, N.R. \& Nogueira, J.M.F. 2012. Development of a bar adsorptive micro-extraction-large-volume injectiongas chromatography-mass spectrometric method for pharmaceuticals and personal care products in environmental water matrices. Analytical and Bioanalytical Chemistry 402(3): 1355-1364.

Płotka-Wasylka, J. 2018. A new tool for the evaluation of the analytical procedure: Green Analytical Procedure Index. Talanta 181: 204-209.

Przyjazny, A. 2019. Extraction: Liquid-phase microextraction, In Encyclopedia of Analytical Science (Third Edition), edited by Worsfold, P., Poole, C., Townshend, A. \& Miró, M. New York: Academic Press. pp. 52-62.

Rezaee, M., Assadi, Y., Hosseini, M.R.M., Aghaee, E., Ahmadi, F. \& Berijani, S. 2006. Determination of organic compounds in water using dispersive liquid-liquid microextraction. Journal of Chromatography A 1116(1-2): 1-9.

Shiri, F., Hashemi, B. \& Sobhani, S. 2017. Central composite design optimization of dispersive liquid-liquid microextraction based on solidification of organic drop for the determination of 5-hydroxymethyl-2-furfural in orange juice using high-performance liquid chromatography. Journal of Analytical Chemistry 72(6): 671-677.

Shishov, A., Volodina, N., Nechaeva, D., Gagarinova, S. \& Bulatov, A. 2019. An automated homogeneous liquidliquid microextraction based on deep eutectic solvent for the HPLC-UV determination of caffeine in beverages
Microchemical Journal 144: 469-473.

Sun, A., Xu, Q. \& Yu, X. 2013. Determination of bisphenol a and 4-nonylphenol in water using ionic liquid dispersive liquid phase microextraction. Polish Journal of Environmental Studies 22(3): 899-907.

Tobiszewski, M., Tsakovski, S., Simeonov, V. \& Namieśnik, J. 2014. Multivariate statistical comparison of analytical procedures for benzene and phenol determination with respect to their environmental impact. Talanta 130: 449-455.

Wang, X., Wu, L., Cao, J., Hong, X., Ye, R., Chen, W. \& Yuan, T. 2016. Magnetic effervescent tablet-assisted ionic liquid dispersive liquid-liquid microextraction of selenium for speciation in foods and beverages. Food Additives \& Contaminants: Part A 33(7): 1190-1199.

Xia, J., Xiang, B. \& Zhang, W. 2008. Determination of metacrate in water samples using dispersive liquid-liquid microextraction and HPLC with the aid of response surface methodology and experimental design. Analytica Chimica Acta 625(1): 28-34

Xu, X., Su, R., Zhao, X., Liu, Z., Zhang, Y., Li, D., Li, X., Zhang, H. \& Wang, Z. 2011. Ionic liquid-based microwaveassisted dispersive liquid-liquid microextraction and derivatization of sulfonamides in river water, honey, milk and animal plasma. Analytica Chimica Acta 707(12): 92-99.

Yan, H., Liu, B., Du, J., Yang, G. \& Row, K.H. 2010. Ultrasoundassisted dispersive liquid-liquid microextraction for the determination of six pyrethroids in river water. Journal of Chromatography A 1217(32): 5152-5157.

Yang, M., Wu, X., Jia, Y., Xi, X., Yang, X., Lu, R. \& Zhou, W. 2016. Use of magnetic effervescent tablet-assisted ionic liquid dispersive liquid-liquid microextraction to extract fungicides from environmental waters with the aid of experimental design methodology. Analytica Chimica Acta 906: 118-127.

Yao, C., Li, T., Twu, P., Pitner, W.R. \& Anderson, J.L. 2011. Selective extraction of emerging contaminants from water samples by dispersive liquid-liquid microextraction using functionalized ionic liquids. Journal of Chromatography A 1218(12): 1556-1566.

Yazdi, A.S., Razavi, N. \& Yazdinejad, S.R. 2008. Separation and determination of amitriptyline and nortriptyline by dispersive liquid-liquid microextraction combined with gas chromatography flame ionization detection. Talanta 75(5): 1293-1299.

Zgoła-Grześkowiak, A. \& Grześkowiak, T. 2011. Dispersive liquid-liquid microextraction. TrAC Trends in Analytical Chemistry 30(9): 1382-1399.

Zeng, H., Qiao, K., Li, X., Yang, M., Zhang, S., Lu, R., Li, J., Gao, H. \& Zhou, W. 2017. Dispersive liquid-liquid microextraction based on the solidification of deep eutectic solvent for the determination of benzoylureas in environmental water samples. Journal of Separation Science 40(23): 4563-4570.

Zhou, P., Zheng, R., Zhang, W., Liu, W., Li, Y., Wang, H. \& Wang, X. 2019. Development of an effervescent tablet 
microextraction method using $\mathrm{NiFe}_{2} \mathrm{O}_{4}$-based magnetic nanoparticles for preconcentration/extraction of heavy metals prior to ICP-MS analysis of seafood. Journal of Analytical Atomic Spectrometry 34(3): 598-606.

Zulkipli, N.A., Loh, S.H. \& Khalik, W.M.A.W.M. 2019. C CTA composite thin film usage as an extraction sorbent for caffeine residue in water analysis. Research Journal of
Chemistry and Environment 23(1): 44-50. Faculty of Science and Marine Environment Universiti Malaysia Terengganu

21030 Kuala Nerus, Terengganu Darul Iman Malaysia

*Corresponding author; email: wan.afiq@umt.edu.my

Received: 18 May 2020

Accepted: 6 July 2020 